\title{
Study on the Strategies of Financial Management in E-Commerce Enterprises
}

\author{
Tu Yuejun \\ NanChang Institute of Science \& Technology
}

\begin{abstract}
Development of modern information technology has changed the traditional ways of production and business, during which a new business mode has emerged, that is, electronic commerce. With its unique advantages, e-commerce has been widely applied in a short time, which has also generated a group of e-commerce enterprises. It is of great significance to establish strategies of financial management suitable for e-commerce enterprises since it is not only helpful for executors to formulate better financial polices, but it is also beneficial to improve enterprises' administration level and market competitiveness. In the paper, it also analyzes new problems existing in the implementation of financial management strategies in e-commerce enterprises with proposal of rational suggestions. The study of this paper is aimed to select rational financial strategies for e-commerce enterprises so as to promote a better development.
\end{abstract}

Keywords-electronic commerce; financial management; strategies

\section{I.INTRODUCTION}

The emergence of electronic commerce is due to the world economic globalization, polarization, motivation of high demand as well as development of computer and network technologies. It is a process of spread and communication of network technologies in economy, society and culture. Since electronic commerce has thoroughly changed current operational means with sufficient usage of limited resources, short business circle period, high operation efficiency, low cost and good service quality, development of electronic commerce has brought unprecedented development opportunities to enterprises and world economy. Promoted by Internet, new enterprise systems have come into being, such as online enterprises, internet enterprises and virtual enterprises and so on. Ecological environment of enterprises has also changed from the previous string mode from suppliers, manufacturers and merchants to customers to the current parallel non-hierarchical mode based on network.

In recent years, domestic studies on electronic commerce enterprises have kept pace with international studies. There are increasingly more books and papers on e-commerce enterprises with more discussions from all walks of life; and meanwhile the contents have involved various aspects like the concept, mode, conditions and environment and so on but with comparatively less studies on finance.

E-commerce enterprises in this paper refer to all business organizations which conduct business activities as well as marketing activities both inside and outside their enterprises by open network and electronic information technologies.

\section{II.ELECTRONIC COMMERCE HAS CHANGED THE MODE OF FINANCIAL MANAGEMENT IN ENTERPRISES}

The first one is centralized financial management More and more enterprises have adopted centralized financial management mode in order to integrate financial resources and improve competitiveness in the fierce market competition. Network finance is an ideal mode of centralize financial management. With network financial system, the large Group company can make accounts and allocate funds collectively in all branches. The subordinate body becomes a financial unit, which can reduce expenditures on accountants in base units.

The second is coordination between finance and business. It has always been an important issue to coordinate business and finance in an enterprise. Finance was hard to be integrated with business due to the timeliness of information transmission before the emergence of Internet. As an important component of electronic business, network finance has promoted the coordination between finance and business fundamentally including coordination among internal departments as well as coordination with social departments. The budget control, preparation of funds, online payment and online settlement in financial department should be coordinated 
with the work in business department. Meanwhile, coordination with supply chain such as online inquiry and online debt dunning should also be well dealt with.

The third aspect is remote treatment. Due to spacial limitation, remote financial management was very difficult with high cost before the emergence of Internet. While this restriction has been broken through with the financial management system based on Internet. Thus the management ability can be extended to anywhere. Remote control has come true, which has significant realistic significance for Group company with many branches.

\section{III.PROBLEMS EXISTING IN THE APPLICATION OF NETWORK} FINANCE IN E-COMMERCE ENTERPRISES.

At present, safety crisis in the application of network finance in e-commerce enterprises are as follows.

Distortion of data. During the application of network finance in e-commerce enterprises, financial data is conveyed through Internet, so there is no confirmation or signature during data transmission. Thus, the completeness and authenticity of data can't be ensured. The common data distortion is mistake, loss or change of accountants' data

Disclosure of information. Since network finance is operated on the Internet, information technology is especially important for financial management. At present, the main form of financial risk is to steal secrete information from enterprises by high-technology.

Abnormal operation of system. The network financial system may break down due to incorrect operation, artificial purposeful damage or computer virus attack. In particular, the computer virus has the most serious damage for its strong concealment and wide communication, which can constitute great threat for the safety of computerization system and remote network transmission.

\section{IV.ANALYSIS ON THE GENERAL FINANCIAL STRATEGIES}

\section{AND GOALS IN E-COMMERCE ENTERPRISES}

In general, there are two kinds of financial strategies and goals.

The first is to maximize profit, that is, the enterprise is aimed to realize a maximum profit. It has two forms. One is to realize a maximum absolute amount, and another is to realize a maximum relative amount. The profit of an enterprise can reflect its economic effect to much degree.
Enterprises should lower their consumption and improve their income to pursue maximum profit, which can greatly improve their development.

The second is to realize maximum values of enterprises. That is, enterprises should pursue long-term stability and healthy development to maximize their market prices, which requires operators to take long-term development into consideration by constantly creating future profit growth point.

E-commerce enterprises are also enterprises, so their financial strategies and goals also include two aspects above. However, compared to traditional enterprises, the customer goals and business process of e-commerce enterprises have changed a lot, during which sharing and transferable electronic information resources have become dominant. The constant increase, update, spread and application of electronic information have deeply affect various aspects of enterprises' production, operation and management. Therefore, the goals of e-commerce enterprises' financial management should take more factors into consideration.

\section{V.CONCLUSION}

The emergence of electronic commerce has brought new opportunities to enterprises since financial business is not restricted to one country or one region. Instead, it has been developed in an international, accurate, computerized and networked way. Under this new circumstance, study on financial management in e-commerce enterprises should be well developed with more attention.

At present, study on the financial management in e-commerce enterprises is mainly concentrated on the innovation of financial management goals and methods. Thus, analysis and study on the financial management strategies in e-commerce enterprises have been made in this paper. Through the analysis, conclusions can be drawn as follows.

Through analyzing the financing features of e-commerce enterprises combined with the properties and costs of different financing ways, we find that the main financing method used by e-commerce enterprises is equity financing.

Through analyzing the development situation of domestic e-commerce enterprises as well as their bearing capacity of risks and financing cost, we find that currently 
e-commerce enterprises should adopt conservative financing structure with equity capital as the main form.

According to the profit situation and development stages of e-commerce enterprises, we suggest that they should adopt zero-dividend or low-dividend allocation policy.

\section{REFERENCES}

[1] Brigham E F, Ehrhardt M C. Financial management theory and practice[J]. Implementing Integrated Water Resources Management in Central Asia, 2005:3-21.

[2] Hilgert M A, Hogarth J M, Beverly S G. Household Financial Management: The Connection between Knowledge and Behavior[J]. Federal Reserve Bulletin, 2003, 89(July):309-322.

[3] Fredrikson E B, Horne J C V, Mock E J, et al. Financial Management and Policy[J]. Journal of Finance, 1969, 24.

[4] Merton R C. A functional perspective of financial intermediation -Financial Management Silver Anniversary Commemoration[J]. Financial Management (Financial ..., 1995, (Summer).
[5] Stern J M, Bennett S G, Chew D H. THE EVA®; FINANCIAL MANAGEMENT SYSTEM[J]. Journal of Applied Corporate Finance, 1995, 8(2):32-46.

[6] Hou Z C, Wei K P. The Data Integration of Financial Management System with Digital Campus Platform[J]. Journal of East China Institute of Technology, 2014.

[7] Zhang Q, Tang Y. Study on Financial Management of Professional Design Institute Transform to EPC[J]. Construction Economy, 2014.

[8] Magee G L. Financial Management Primer For New Project Managers[J]. Journal of Management in Engineering, 2014, 12(5):62-67.

[9] Jie-Rong X U. Construction of Private Enterprises' Financial Management Standardization[J]. Journal of Hubei Radio \& Television University, 2014

[10] Chang Q, Lin-Fei W U, Kong L H, et al. Research on the Model of Lean Financial Management in Enterprises:A Case Study of the Financial Management of Shendong Coal Group[J]. Journal of Management Case Studies, 2014.

[11] Salikin N, Wahab N A, Muhammad I. Strengths and Weaknesses among Malaysian SMEs: Financial Management Perspectives[J]. Procedia - Social and Behavioral Sciences, 2014, 129:334-340.

[12] Santos M A, Madeira F C, Passos S R, et al. Autonomy for financial management in public and private healthcare facilities in Brazil[J]. Cad Saúde Pública, 2014, 30(1):201-206. 